\title{
Semantic Representation of Social and Role Identification in Subject Self-Organization of Personality
}

\author{
Семантическая репрезентация \\ социально-ролевой идентификации в \\ субъектной самоорганизации личности
}

\author{
Sergey Dyakov \\ Ph.D. in Psychology, \\ Associate Professor
}

\section{Сергей Дьяков}

кандидат психологических наук, доцент

\author{
Email: astropsiyoga@gmail.com \\ https://orcid.org/0000-0002-4929-8640 \\ ResearcherID: V-8266-2018
}

Sevastopol State University

33, University Str., Sevastopol, 299053
Севастопольский государственный
университет
$\bigotimes \cdot$ ул.·Университетская, 33 , Севастополь, 299053

Original manuscript received November 05, 2018

Revised manuscript accepted March 08, 2020

\begin{abstract}
Objective. Based on the psycholongvistic approach, which is widely represented in world personology and psychosemantics, revealing the subjective descriptive characteristics of a person, an attempt is made to build a model and diagnostic technique for mental personality self-organization (PSO).

Material and method. The psycholinguistic method of theoretical structuring and systematization of scientific and theoretical data is presented in the perspective of the subjective paradigm and methodology of the system-synergetic approach (psychological and philosophical) is presented in the construction of a categorical-conceptual model of subjectivity in PSO. Based on the method of categorical-conceptual modeling, a model and methodology for semantic analysis and assessment of subjectness
\end{abstract}

\section{ISSN 2309-1797(print)/2415-3397 (online)}


self-organization of personality based on individual characteristics of the experience of social-role identification, reflecting the characteristics of feelings and constructs of understanding that determine the conscious will of the subject, is developed.

Results. Psycholinguistic scales of semantic constructs are highlighted of the psychic (functional and motivational) and activity (professional, business, and creative) levels of subjectivity are distinguished. The empirical material reflects the verification of the semantic model and methodology. Modified repertoire lattices by J. Kelly and expert assessment in semantic analysis and classification of constructs served as a method of collecting empirical data. An array of constructs obtained $(N=2000)$ reflects the wellknown categorical-conceptual aspects of psychic phenomena (processes-statesproperties) and external environmental and sociocultural characteristics, thus revealing the socio-psychological aspects of social-role personality identification, which allows analysis and subjectness assessment. Findings. The presented semantic scales of qualities and personality traits (factors of socio-psychological identification) reveal the systemic relationship and the level structure of the PSO, and also make it possible to assess subjectness.

Key words: categorical conceptual modeling, mental self-organization, systemsynergetic approach, subject, personality subjectness, social role identification.

\section{Вступление}

Требования современных психологических исследований определяются концепцией фундаментальной науки (Лефевр, 1991; Ломов, 1984 и др.) и системно-синергетическим подходом (Богданов, 1987; Дьяков, 2014-2018; Ломов, 1984; Haken, 1995 и др.). В свою очередь семантический подход, в ракурсе когнитивной науки, можно определить как ведущий в современных психологических исследованиях в силу того, что познание и опыт человека составляют информационную систему знания (отраженную в лексике языка и представляющую объект психолингвистики (Chomsky, 2000; Harley, 2009; Steinberg \& Sciarini, 2013 и др.), преломленную через систему социокультурных значений о тех или иных вещах мира, которые будучи пережиты и осознаны субъективном понимании, связываются в смыслообразующие мотивационно-ценностные структуры и механизмы, определяющие персональные характеристики отношения человека как субъекта к миру, жизни и себе самому (Дьяков, 2016а).

В изучении психологических свойств личности исследователями используется психолингвистический подход 
С емантическая репрезентация социально-ролевой идентификаџии...

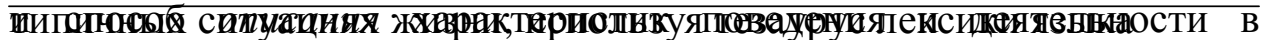
(Kettell, 1943; Allport \& Odbert, 1936; Hall \& Lindsey, 1970; Borgatta, 1964). В результате построены модели личности: двухфакторная и трехфакторная (Aizenk, 1997); трехфакторная (Osgood, 1956); четьрехфакторная (Kettell, 1943); пятифакторная «Big five» (McCrae et al., 2004); шестифакторная «HEXACO» (Ashton et al., 2004); семифакторная (Almagor, Tellegen \& Waller, 1995); многофакторная «MMPI» (McKinley \& Hathaway, 1944 и др.). В психосемантических исследованиях сохраняется такой же подход (Артемьева, 1999; Петренко, 2005; Серкин, 2017 и др.). Однако это не позволяет объяснить какие психические механизмы (интеллекта, эмоций и чувств, воли, темперамента и характера, способностей и мотивации и др.) обуславливают аспекты поведения и деятельности, а тем более раскрыть иерархию системы самоорганизации жизни субъектом, т.е. определить принципы и закономерности психической самоорганизации (ПСО) личности (Дьяков, 2016а, 2018).

В аспекте психосемантического подхода в мировой психологии сделана ориентация на изучение сущностной стороны человека (Артемьева, 1999; Леонтьев, 2003; Менегети, 2015; Мэй, 1997; Сартр, 2000; Фромм, 2006; Grof, 2000; Maslow, 1991 и др.), которая отражается в его субъектности (самоорганизованной активности), и раскрывается в перспективе использования им своих прав и свобод (Брушлинский, 2003), раскрывая индивидуальные потенциалы способностей и творческой мотивации.

В ракурсе субъектной парадигмы и системно-синергетического подхода (Ананьев, 1968; Анохин, 1975; Левин, 2001; Ломов, 1996; Пригожин \& Стенгерс, 1986; Haken, 1995) обозначена ориентация на новый предмет психологии - субъект психической самоорганизации (Дьяков, 2016а). Институт психологии РАН с 90-х годов, на протяжении последних 30-ти лет разрабатывал проблему субъекта как ведущую, но вопросы структуры и механизмов субъекта остаются открытыми (Брушлинский, 2003; Сергиенко, 2013 и др.). Мало разработанной является также онтологическая (Сергиенко, 2013 и др.) и методологическая стороны исследования субъектности человека. Таким образом, актуальными сегодня являются задачи, связанные с определением критериев и разработкой моделей психической самоорганизации субъекта и субъектности личности, 
а также методов анализа и оценки субъектности. Понятие субъекта многими исследователями раскрывается в свойствах сознательности, самостоятельности активности и свободы воли (Артемьева, 1999; Брушлинский, 2002; Дьяков, 2016a, 2016b). Задача состоит в выявлении категориальной структуры сознания, выраженной в вербально-лингвистических конструктах, отражающих механизмы психологической самоорганизации в личностной идентификации.

Нами сделана попытка структурировать и систематизировать научно-теоретические психолингвистические данные, отраженные в научно-психологических и философских категориях, моделях и концепциях, в построении категориально-концептуальных моделей (Дьяков, 2014-2018). Данный метод имеет характер теоретического структурирования и систематизации научных категорий и концепций и назван нами методом категориально-концептуального моделирования. Вместе с тем в статье представлено эмпирическое исследование, направленное на построение и верификацию семантической модели и метода исследования субъектной самоорганизации личности.

Цель работы. Используя метод категориальноконцептуального моделирования, в психолингвистическом поле конструктов личностной идентификации, разработать модель и методику семантического анализа и оценки субъектной самоорганизации личности на основе индивидуальных особенностей опыта социально-ролевой идентификации, отражающих особенности чувств и понимания, детерминирующих сознательную волю субъекта. По мнению Б.Ф. Ломова:

«Внутренний мир человека, его психологическое пространство «в действительности выступает именно как отражение, но сложно организованное, «накопление» в течении жизни, включающее многие уровни глубины и полноты осознаваемого и неосознаваемого и характеризует уникальность каждой личности, ее своеобразие» (Ломов, 1984: 189).

Поэтому, можно предположить, что модель субъектной самоорганизации личности должна включать разные формы и уровни информационно-семантических механизмов, отражая «... полносистемный способ существования человека» (Ломов, 1984: 177). Также гипотезой служило положение, что субъектные 
С емантическая репрезентация социально-ролевой идентификаџии...

свойства (самостоятельность организации активности) связаны с волевыми качествами личности (Дьяков, 2014-2018).

Построение такой системной семантической модели подготовлено исследованиями и теориями отечественной психологии: теорией деятельности, установки, системной организации психических процессов и функций, развития и организации высших психических функций, отношения, индивидуальных различий и развития, теории систем и синергетики и др. Системоорганизующие принципь и метод моделирования занимают ведущее положение в психологии (Богданов, 1987; Дьяков, 2016а, 2018; Никандров, 2003; Aizenk, 1997; Allport \& Odbert, 1936; Kettell, 1943; McCrae et al., 2004 и др.), придя на смену аналитической парадигме. В свою очередь семантика в отечественной психологии направлена на изучение (моделирование) структур сознания личности, однако «при позищионной четкости проблемь конструктивного ее решения пока не предложено» (Артемьева, 1999: 10). Вместе с тем не представлены еще модели, отражающие целостную многоуровневую (включая сознательные и неосознаваемые уровни) семантическую систему человека, а также модели субъекта и субъектности (самоорганизации человеком своей жизни и деятельности с помощью самоорганизации своей психики). Принципиальным в изучении и построении модели субъектности личности является семантический подход в психолингвистике и психосемантике, где осуществляется моделирование систем значений и атрибуций стимулов, допускающих интерпретацию на языке значений (Артемьева, 1999; Серкин, 2017; Chomsky, 2000; Harley, 2009; Menn, 2016; Osgood, 1956; Steinberg \& Sciarini, 2013), смыслов и ценностей (Шварц, 2008; Schwartz et al., 2012). В то же время, в целях семантического моделирования важным является изучение (анализ, классификация, структурирование, систематизация) научнотеоретической базы психологии, составляющей концептуальнокатегориальную систему интерпретации психических явлений (Дьяков, 2014-2018).

В соответствии с тезисом Дж. Келли (Kelli, 1955) о том, что каждый человек является исследователем, его семантическая система персонального опыта, в когнитивном аспекте, приобретает статус оригинальности. Жизненный опыт человека-исследователя составляют семантическое пространство альтернативных 
конструктов значений, отражающих особенности чувств, понимания и оценки им людей, вещей и идей бытия. Персональная семантическая модель мира и себя в нем, а также смысла жизни и самореализации личности как субъекта (в итоге - раскрытие своей интенции, достижение своего акме) - есть его личная ценностносмысловая модель жизни. Эта семантическая модель создается и развивается субъектом на основе опыта ролевого взаимодействия в социокультурной среде. Ее характеристики выступают в его сознании как система лингвистических категорий и когнитивных теорий, базирующихся на чувственном непосредственном опыте человека. В связи с этим, представленная нами семантическая модель имеет котегориально-концептуальное строение (отражаемое социально-психологической лексике и научных теориях).

Также проблема субъектности и вопросы понимания значения вещей человеком рассматривается в психолингвистическом контексте в современном герменевтическом подходе в психологии, котором отражена социокультурная самодерминация личности (Чепелева \& Рудницкая, 2019; Habermas \& de Silveira, 2008; Hammack, 2008; McLean, Pasupathi \& Pals, 2007 и др.). Здесь речь идет о дискурсивном самопроектировании через осмысление социокультурного и индивидуального опыта, а также о семантическом нарративе событий опыта в становлении индивидуальности (Зайцева, 2016 и др.).

Ориентиром в системологическом моделировании самоорганизации человека послужила работа В. Богданова (Богданов, 1987), в которой теоретически раскрыта модель о соотношении личностных качеств с психологическими механизмами (в аспекте социальной психологии). Это собственно и направляет нас к собственно психическим механизмам, а не переключает на поведенческие характеристики, как это выглядит в большинстве современных описательных моделей личности, использующих психолингвистический подход. «Конечно, это не касается моделей личности С. Рубинштейна, К. Платонова, 3. Фрейда и других исследователей, которые раскрывают в них факторы психической самоорганизации личности» (Гамезо \& Домашенко 2004: 65). Отсюда очевидна необходимость объединения этих двух подходов (психодинамического и когнитивно-поведенческого) для получения целостной системы субъектно-личностной самоорганизации 
жизнедеятельности индивида. Тогда мы будем понимать какие психические механизмы стоят за поведенческой природой личности как они системноиерархически самоорганизованы. А также сможем их измерить и сделать оценку. Данный аспект хорошо виден в разделении на подходы мировых школ психотерапии (Карвасарский, 2002): психодинамический и когнитивноповеденческий и экзистенциально-гуманистический.

В. Богдановым (1987) были построена матрица, в которой горизонтальные графы обозначены психическими процессами, а вертикальные - психическими свойствами личности (Табл. 1).

Таблица 1. Классификационная матрица личностных свойств, отобравших влияние подструктур личности на течение психических процессов

\begin{tabular}{|c|c|c|c|c|c|c|c|}
\hline & $\mathbf{C}$ & $\mathbf{T}$ & I & $\mathbf{R}$ & $\mathbf{N}$ & $\mathbf{E}$ & $\mathbf{P}$ \\
\hline $\mathbf{v}$ & $\begin{array}{l}\text { Упорство - бе- } \\
\text { звольность }\end{array}$ & & $\begin{array}{l}\text { Организо- } \\
\text { ванность - } \\
\text { безала- } \\
\text { берность }\end{array}$ & & $\begin{array}{l}\text { Настойчи- } \\
\text { вость - по- } \\
\text { рывистость }\end{array}$ & & \\
\hline e & $\begin{array}{l}\text { Мужество - } \\
\text { трусость }\end{array}$ & $\begin{array}{l}\text { Эмоцио- } \\
\text { нальность - } \\
\text { сухость }\end{array}$ & & & $\begin{array}{l}\text { Удовлетво- } \\
\text { ренность - } \\
\text { неудовлетво- } \\
\text { ренность }\end{array}$ & & \\
\hline c & $\begin{array}{l}\text { Решительно- } \\
\text { сть - нереши- } \\
\text { тельность }\end{array}$ & & $\begin{array}{l}\text { Рассудо- } \\
\text { чность - } \\
\text { бездум- } \\
\text { ность }\end{array}$ & $\begin{array}{l}\text { Сообрази- } \\
\text { тельность - } \\
\text { недогадли- } \\
\text { вость }\end{array}$ & $\begin{array}{l}\text { Расчетли- } \\
\text { вость - сума- } \\
\text { сбродство }\end{array}$ & $\begin{array}{l}\text { Мудрость - } \\
\text { наивность }\end{array}$ & \\
\hline $\mathbf{p}$ & $\begin{array}{l}\text { Категорич- } \\
\text { ность - мни- } \\
\text { тельность }\end{array}$ & $\begin{array}{l}\text { Впечатли- } \\
\text { тельность - } \\
\text { толстоко- } \\
\text { жесть }\end{array}$ & $\begin{array}{l}\text { Понят- } \\
\text { ливость - } \\
\text { тупоумие }\end{array}$ & $\begin{array}{l}\text { Восприим- } \\
\text { чивость - } \\
\text { отрешен- } \\
\text { ность }\end{array}$ & $\begin{array}{l}\text { Любопыт- } \\
\text { ство - } \\
\text { скучливость }\end{array}$ & $\begin{array}{l}\text { Пресы- } \\
\text { щенность }\end{array}$ & $\begin{array}{l}\text { Наблюда- } \\
\text { тельность }\end{array}$ \\
\hline $\mathbf{a}$ & $\begin{array}{l}\text { Устрем- } \\
\text { ленность - } \\
\text { разбросанность }\end{array}$ & $\begin{array}{l}\text { Тревож- } \\
\text { ность - } \\
\text { спокойствие }\end{array}$ & & $\begin{array}{l}\text { Вниматель- } \\
\text { ность - рас- } \\
\text { сеянность }\end{array}$ & $\begin{array}{l}\text { Сосредото- } \\
\text { ченность - } \\
\text { суетливость }\end{array}$ & & \\
\hline $\mathbf{m}$ & & & & & & $\begin{array}{l}\text { Памят- } \\
\text { ливость - } \\
\text { забыв- } \\
\text { чивость }\end{array}$ & \\
\hline $\mathbf{t}$ & & & $\begin{array}{l}\text { Изобрета- } \\
\text { тельность }\end{array}$ & & $\begin{array}{l}\text { Мечтательно- } \\
\text { сть - прак- } \\
\text { тичность }\end{array}$ & & $\begin{array}{l}\text { Фанта- } \\
\text { зерство }\end{array}$ \\
\hline
\end{tabular}

Интерпретация символов: v - воля, е - эмоции, с - мышление, p восприятие, а - внимание, $\mathrm{m}$ - память, і - воображение; C - характер, темперамент, I - интеллект, В - сознание, М - мотивация, Е - опыт, $\mathrm{P}$ способности. 
Данный автор не подвергал свою модель экспертной проверке и как видно из результатов в таблице 1 , например, мужество - трусость отнесены к эмоциям и характеру, но мужество очевидно является волевым качеством, a трусость связана с эмоциональной тревожностью. В нашем исследовании мы столкнулись с такой проблемой и предложили ее решение.

Системологический подход разрабатывался также В. Мерлиным (Мерлин, 2005) в концепции интегральной индивидуальности (уровень организма, уровень индивидно-личностных свойств, уровень субъекта социальных отношений), однако в его работах также не раскрыты системноинтегративные психические механизмы и принципы самоорганизации. Попытки решения данных задач представлены в наших исследованиях (Дьяков, 2016а), однако в данной статье мы ограничимся нашей целью.

\section{Методы и методики исследования}

Методами получения эмпирических данных в исследовании послужили: репертуарные решетки (Франселла \& Баннистер, 1987; Kelli, 1955); метод семантического анализа в экспертной оценке данных. Полученный (с помощью репертуарных решеток массив семантических конструктов был классифицирован (с помощью семантического анализа в экспертной оценке) и структурирован (в аспекте психологических категорий и концепций по формам психических явлений и внешне средовым факторам) в разработке семантической модели и методики анализа и оценки субъектности (Табл. А. 1, А. 2; Приложение А; Дьяков, 2014, 2015, 2016).

\section{Организация исследования}

Исследование проводилось на протяжении 2002-2019 гг. Выборка респондентов составили около 2000 чел. Для классификации и структурирования массива семантических конструктов по критериям социально-ролевой идентификации (по «реп-тесту») были задействованы эксперты (160 чел.: студенты выпускных курсов и преподаватели университетов). За указанный период модель претерпела изменения (Дьяков, 2015, 2016а). Представленная семантическая модель 
С емантическая репрезентация социально-ролевой идентификаџии...

(Табл. А. 2; Приложение А) отражает законченную структуру социально-ролевой субъектной самоорганизации личности.

\section{Результаты и дискуссии}

Первоначально предполагалось, что субъектные свойства (самостоятельность, активность) связаны с волевыми качествами (В) в психической самоорганизации (ПСО) личности (Дьяков, 2014, 2015, 2016а). Результаты, полученные в пилотаже с помощью «реп-теста» J. Kelli (классический вариант (Франселла \& Баннистер, 1987) и адаптированные к среде (Дьяков, 2014, 2015, 2016а) были классифицированы относительно трех основных функциональных сторон психики: волевой (В), эмоциональной (Э) и интеллектуальной (И). Однако конструкты данных психических сфер имеют сложную природу. Волевые конструкты (В) в последующем были разделены на функциональные волевые (шк. 1) и морально-волевые (отдельные конструкты шк. 4, см. прилож. А, табл. 1). Эмоциональные конструкты (Э) также разделены на эмоции как функции и высшие эмоции - чувства. В результате возник второй уровень семантической самоорганизации в «Индивидуально-психологической сфере» (ИПС): 1-й - Функциональный психический уровень; 2-й Чувственно-мотивационный уровень, включающий устойчивые осознаваемые отношения-мотивы («Мотивационный уровень»: шк. 4-6). Сюда же, вместе с моральными (шк. 4), вошли интеллектуальные чувства-мотивы (шк. 5) и эстетические (шк. 6) (табл. 1, прилож. А). В данном русле разрабатывалась техника семантического исследования субъектности личности (Дьяков, 2014, 2015, 2016а). Также были выделены конструкты, репрезентирующие внешние аспекты идентификации в ПСО. Вначале был выделен фактор физических качеств (внешний вид и т.п.). Затем собственно психические компоненты (В, И, Э) были отражены в свойствахкачествах поведенческой и деятельностной активности. Была обозначена «Индивидуально-действенная сфера» (ИДС). Вместе с тем, конструкты, относящиеся к указанным шкалам (1-14), были классифицированы на предмет самостоятельности в организации активности (субъектности). Конструкты субъектности помечены в табл. 1 звездочкой в графе номера. Так конструкты волевых 
функций (шк. 1) полностью отвечают субъектности. Конструкты ЭФ (шк. 2) не выражают СА, так как раскрывают свойства, нарушающие устойчивость и произвольный контроль. ИФ (шк. 3) раскрывают как активные, так и пассивные качества. Эмоции как высшие психические функции - чувства раскрывают моральные эстетические, интеллектуальные позиции отношения, ценностей и мотивации (шк. 4-6). В ИДС также выделены субъектные конструкты, отражающие СА и конструкты выражающие аспекты непосредственности, пассивности, резонансности в социальноролевой идентификации (шк. 9-14). Конструкты внешне-адаптивной сферы (BAC) не были включены в состав субъектный свойств идентификации и самоорганизации (шк. 15-20). Они отражают особенности восприятие себя и понимания своего положения в условиях внешней среды.

В результате полученное структурное распределение конструктов позволяет выделить субъектные свойства и произвести психодиагностическое измерение. Это производится путем подсчета в бланке результатов по «реп- тесту» конструктов субъектности (помечены звездочкой в табл. 1). При этом распределяя их соответственно сферам анализа и оценки на «интросубъектный» (шк. 22) и «экстрасубъектный» (шк. 23) уровни и вычисляя общий показатель субъектности (шк. 21).

Данная модель была подвергнута процедуре экспертной оценки (процедуру см. в Прилож. А; Табл. 2 представляла ранний вариант из 20 шкал) и на последнем этапе была выявлена дополненная структурный компонент и интегрирующий уровень ПСО «Смысложизненный уровень» (интегральные ценности-мотивы - шк. 7, 8). Таким образом, «Индивидуально-психологическая сфера» (ИПС) отражает 3 уровня ПСО (рис. 2), которые, как выяснилось (Дьяков, 2016а), иерархически взаимосвязаны и подтверждают положение синергетики: «Параметры порядка, формирующиеся в системе более высокого уровня иерархии, становятся управляющими параметрами для подсистем более низкого уровня» (Мещеряков \& Зинченко, 2003). Иерархическое распределение структурных уровней эмпирически обосновано нами в эксперименте с исследованием механизмом «сдвига мотива на цель» (Дьяков, 2016b).

В свою очередь, данная система ПСО раскрывается в самоорганизации поведения и деятельности, а взаимодействие 
С емантическая репрезентация сочиально-ролевой идентификации...

психической и практической сфер активности ведет к их преобразованию и развитию.

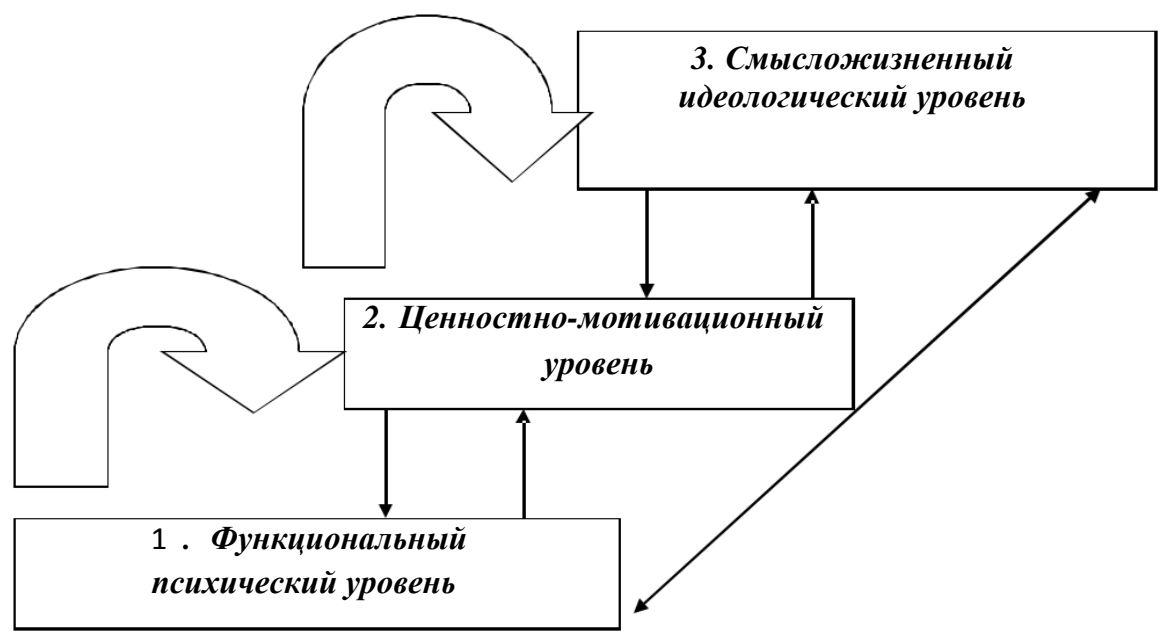

Рис. 2. Иерархическая модель системы психической самоорганизации личности

\section{Результаты исследования}

В данной статье отражен материал заключительного структурирования семантической модели субъектности личности. Анализ, представленный экспертами (160 чел.: студенты и преподаватели психологии), показал следующие результаты (Табл. А. 1, А. 2; Приложение А).

(1) В моделировании семантической структуры субъектности личности найдены структурно-функциональные связи, которые определяют систему сознательной концептуализации ею социальных отношений.

(2) Респонденты не психологического профиля затрудняются и часто не способны дать оценку распределения конструктов по шкалам данной структуры, в силу отсутствия у них специальных психологических знаний. Поэтому значительная часть лиц, привлеченных для экспертизы, не могли выполнить классификацию конструктов. Известно, что у истоков становления научной психологии, В. Вундтом (Вундт, 2002) и Э. Титченером (Titchener, 1901-1906) разрабатывался метод интроспекции. Данный метод на то время был главным и даже единственным средством познания психических явлений (аспектов сознания), «открытых» 
Semantic Representation of Social and Role Identification...

непосредственно только индивидуальному самонаблюдению. Критика данного подхода состояла в том, что только психологспециалист может проводить интроспекцию, так как несведущийв психологии человек не понимает и не может правильно отражать происходящее в его психике. В нашем исследовании подтвердилось положение о том, что сделать объективный анализ и классификацию психологических явлений, выполнять сложные операции, структурирования и систематизации действительно может только психолог-специалист, который компетентен в области психологических категорий и владеет структурой и содержанием психологии.

(3) Конструкты, которые составляют полярные качества функционального уровня ИПС показывают следующее.

В некоторых случаях, среди конструктов, определяющих волевые функции (шк. 1), один полюс (например, левый) относится к волевой сфере, а другой к эмоциональной (например, смелость трусость; рискованность - нерешительность, робость). Тогда как конструкты, составляющие эмоциональные функции раскрывают только эмоциональную сферу реагирования и состояний человека. Данное семантическое соотношение раскрывает связь полюсов конструктов, определяющих волевые функции с эмоциональными, что составляет, как известно, в психологии эмоционально-волевую сферу личности. В свою очередь последняя определяется как характер, в котором раскрывается мотивационно-ценностная сторона (шк. 4, 5, 6) принципов и убеждений личности (ее направленность), мировоззрение и система смыслообразующих целей и способов их реализации (шк. 7, 8). Данные конструкты выделены как аспекты собственно психических сфер личности, и составляют механизмы целостной системы психического функционирования, с помощью которой он как субъект самоорганизовывается (Дьяков, 2016), существует (самоидентифицируя себя со своей психикой в

поле рефлексии сознания) и осуществляет саморегуляцию и самоуправление своими внутренними психическими процессами и состояниями в самоорганизации жизнедеятельности.

(4) Конструкты, составляющие «Функциональный психический уровень» (ФПУ - шк. 1, 2, 3) «Индивидуальнопсихологической сферы» № I (ИПС), отражают внутренние механизмы и факторы психической системы самоорганизации, 
саморегуляции и самоуправления личности. Экспертами отмечено, что данные конструкты (ФПУ) сферы № I (ИПС) характеризуют также собственно качества (черты) личности, т. е. определяют внешние проявления личности, принадлежащие к сфере № II «Индивидуально-действенной сферы (ИДС)» личности. Например, независимость - конформность, решительность - нерешительность (вол. функции); эмоциональность - неэмоциональность (эм. ф.); рассудительность - безрассудство (инт. ф.). Это показывает, что внутренние психические механизмы (система в целом) складываются в процессе внешнего поведения и деятельности человека и, в свою очередь, отражают аспекты поступков и действий индивида, развиваясь через внешние практические проявления и детерминируя внешнюю наблюдаемую сторону жизнедеятельности личности в обществе.

(5) К психической сфере № I относятся также конструкты, которые составляют внутренний «Мотивационный уровень» ИПС самоорганизации. Данные конструкты также можно отнести к указанной внешней поведенческо-деятельностной сфере ИДС, то есть, они, как «ценности-принципы-мотивы», определяют манеру, стиль поведения и деятельности личности - eе характер и способности. Например, качества: старательность, эгоизм, аккуратность (моральные чувства); любовь к прекрасному, хороший вкус (эстет. ч.); рассудительность, любознательность (интеллектуальные чувства). Следовательно, аспекты ценностей и мотивации личности отражаются в ее поведении и деятельности, и, в свою очередь, претерпевают изменение и развитие в результате обратной связи с внешними практическими характеристиками. Это раскрывает диалектику взаимоотношений внешних практических и внутренних психических свойств, детерминацию ПСО человека как субъекта, стремящегося сознательно строить свою жизнедеятельность.

Таким образом, мы выделяем в моделировании ПСО личности внутренние психические детерминанты как аспекты семантической репрезентации личного опыта жизни, а также идентифицированных форм и качеств социально-ролевого поведения (в том числе и культурно-исторического опыта как идеологии человечества, отраженной в идеях и ценностях народов и культур), определяющие его внешние действенные личностные характеристики субъектности. 
Вместе с тем, внутренние аспекты ИПС личности, составляющие свойства и факторы ее социально-психологической адаптации, т. е. по сути ее ПСО (субъективный мир опыта и психические механизмы, а также когнитивно-ценностно-мотивационные паттерны реакций и поступков), часто раскрываются не как субъектно самодетерминированные (на основе самостоятельного выбора и принятия решения) намерения самоактуализации сущностной (рефлексируемой в переживаниях им своих чувств и мыслей как аспектов собственного «Я») стороны, а отражают социокультурные стереотипы.

Отмеченные аспекты связей и взаимоотношений выделенных семантических шкал психологических качеств и свойств в структуре анализа и оценки субъектности личности (факторы социальнопсихологической идентификации) указывают на системную взаимосвязь этих компонентов, а также на существование уровневой структуры и динамики составляющих ПСО личности, субъектноинтегративным фактором в которой является сознание, позволяющее человеку, находясь в окружении других людей как носителей сознания и субъектности, осуществлять, в рамках своего познания и понимания себя, мира и жизни, субъектную (осознанную) самоорганизацию жизни и деятельности.

По результатам исследования некоторые конструкты, которые в начале были отнесены к сфере эстетических мотивов (эти мотивы занимают высшую ступень в пирамиде А. Маслоу (Maslow, 1991), относительно моральных и интеллектуальных), сформировали отдельный интегральный «Смысложизненный уровень» (шк. 7, 8), в котором «интегральные ценности-мотивы» относятся также к ИПС. Сюда отнесены такие качества как счастье, жизнерадостность, оптимизм, энтузиазм и др.

Конструкты субъектности помечены звездочкой (Табл. А. 1). Получена высокая экспертная согласованность по распределение конструктов по шкалам и относительно субъектностных свойств личности $(0,75-0,9)$. Сложность представила ситуация разделения в понимании субектных и субъективных свойств, где последние отражают все содержание представленных конструктов.

Также, произведены некоторые изменения в наименовании шкал, относительно начального варианта (Табл. 1): 4.3 «профессиональные склонности»; 4.4 «профессионально-деловые 
способности» и добавлена шкала 5.4 «возрастные данные». В табл. 1 отражен не весь массив конструктов, полученных в исследовании. Сокращены синонимичные пары.

\section{Выводы}

Полученные данные позволяют говорить о законченности разработанной модели. Массив полученных психолингвистических конструктов отражает известные категориально-концептуальные аспекты психических явлений (процессов-состояний-свойств) и внешних средовых и социокультурных характеристик, раскрывая, таким образом, социально-психологические стороны и сферы социально-ролевой идентификации личности, и дает возможность производить анализ и оценку субъектности. Процедура и результаты использования семантической модели в исследовании социальноролевой идентификации и субъектности личности (с использованием репертуарных решеток Дж. Келли (Kelli, 1955)) раскрыта в наших работах (Дьяков, 2014-2018). Представленные семантические шкалы психолингвистических конструктов качеств и свойств личности (факторы социально-психологической идентификации) раскрывают системную взаимосвязь и уровневую структуру ПСО личности, также позволяют сделать оценку с целью коррекции и развития субъектности (Дьяков, 2016а).

\section{Литература}

Ананьев, Б.Г. (1968). Человек как предмет познания. Ленинград: ЛГУ.

Анохин, П.К. (1975). Очерки по физиологии функцииональных систем. Академия медицинских наук СССР. Москва: Медицина.

Артемьева, Е.Ю. (1999). Основы психологии субъективной семантики. Москва: Наука; Смысл.

Богданов, В.А. (1987). Системологическое моделирование личности в социальной психологии. Ленинград: Изд-во ЛГУ.

Брушлинский, А.В. (2002). Психология субъекта: индивида и группы. Психологический журнал, 23 (1), 72-80.

Вундт, В. (2002). Введение в психологию. Санкт-Петербург: Питер.

Гамезо, М.В., \& Домашенко, И.А. (2004). Атласпо психологии. Москва: Педагогическое общество России.

Дьяков, С.И. (2014). Модель семантического анализа и оценки субъектности личности. П Психологическая диагностика, 1, 36-56. 
Дьяков, С.И. (2015). Субектность педагога. Семантические модели и технология исследования (2-е изд.). Москва: ФЛИНТА: Наука.

Дьяков, С.И. (2016а). Механизм «сдвига мотива на цель» в семантической системе психической самоорганизации субъекта. Теоретическая и экспериментальная психология, 9 (4), 87-100.

Дьяков, С.И. (2016b). Семантика самоорганизации человека как субъекта жизни. Основы психологии субъекта. Санкт-Петербург: Проспект Науки.

Дьяков, С.И. (2017). Психосемантический подход в методологии исследования самоорганизации человека как субъекта жизни. Мир психологии, 4, 148-157.

Дьяков, С.И. (2018). Психическая самоорганизация человека как субъекта жизни. Семантический принцип. Известия Иркутского государственного университета. Серия Психология, 23, 15-27.

Зайцева, Ю.Е. (2016). Я-нарратив как инструмент конструирования идентичности: экзистенциально-нарративный подход. Вестник СПбГУ, 16 (1), 118-136.

Карвасарский, Б.Д. (2002). Психотерапия (2-е изд.). Санкт-Петербург: Питер. Левин, К. (2001). Динамическая психология. (Перевод с нем. и англ. Е. Патяевой \& Д. Леонтьева). Москва: Смысл.

Леонтьев, Д.А. (2003). Психология смысла: природа, строение и динамика смысловой реальности (2-е изд.). Москва: Смысл.

Лефевр, В.А. (1991). Формула человека: Контурь фундаментальной психологии. Москва: Прогресс.

Ломов, Б.Ф. (1984). Методологические и теоретические проблемы психологии. Москва: Наука.

Ломов, Б.Ф. (1996). Системность в психологии. Москва: Изд-во «Институт практической психологии», Воронеж: НПО «МОДЭК».

Менегети, А. (2005). Введение в онтопсихологию. Москва: Издательство: БФ «Онтопсихология».

Мерлин, В.С. (2005). Психология индивидуальности: Избранные психологические mpyды. Е.А. Климов (Ред.). Москва: Издательство Московского психологосоциального института.

Мещеряков, Б.Г., \& Зинченко, В.П. (Ред.). (2003). Большой психологический словарь. Москва: Издательство: Прайм-Еврознак.

Мэй, Р. (1997). Любовь и воля. Москва: Рефл-бук; Киев: Ваклер.

Никандров, В.В. (2003). Метод моделирования в психологии. Санкт-Петербург: Речь.

Петренко, В.Ф. (2005). Основы психосемантики. Санкт-Петербург: Питер.

Пригожин, И., \& Стенгерс, И. (1986). Порядок из хаоса: Новый диалог человека с природой. (Пер. с англ.). В.И. Аршинов, Ю.Л. Климонтович \& Ю.В. Сачков (Ред.). Москва: Прогресс.

Сартр, Ж. (2000). Бытие и ничто. Опыт феноменологической онтологии. Москва: Республика.

Сергиенко, Е.А. (2013). Проблема соотношения понятий субъекта и личности. Психологический журнал, 34 (2), 5-16.

Серкин, В.П. (2017). Психосемантика. Москва: Юрайт.

Франселла, Ф., \& Баннистер, Д. (1987). Новый метод исследования личности. Москва: Прогресс.

Фромм, Э. (2006). Бегство от свободы. Человек для себя. Москва: АСТ. Чепелева, Н., \& Рудницкая, С. (2019). Дискурсивні технології особистості, що самопроектується. $\quad$ Psycholinguistics, $25 \quad$ (1), 363-383. https://doi.org/10.31470/2309-1797-2019-25-1-363-383 
Шварц, Ш. (2008). Культурные ценностные ориентации: природа и следствия национальных различий. Психология, 2, 36-67.

Aizenk, H.J. (1997). Personality and experimental psychology: The unification of psychology and the possibility of a paradigm. Journal of Personality and Social Psychology, 73, 1224-1237. https://doi.org/10.1037/0022-3514.73.6.1224

Allport, G.W., \& Odbert, H.S. (1936). Trait-names: A psycho-lexical study. Psychological Monographs, 47, (No. 211). https://doi.org/10.1037/h0093360

Almagor, M., Tellegen, A., \& Waller, N. (1995). The Big Seven Model: A cross-cultural replication and further exploration of the basic dimensions of natural language of trait descriptions. Journal of Personality and Social Psychology, 69, 300-307. https://doi.org/10.1037/0022-3514.69.2.300

Ashton, M., Kibeom, L., Perugini, M., Szarota, P., de Vries, R.E., ... de Raad, B. (2004). A Six-Factor Structure of Personality-Descriptive Adjectives: Solutions From Psycholexical Studies in Seven Languages. Journal of Personality and Social Psychology, 86 (2), 356-366. https://doi.org/10.1037/0022-3514.86.2.356

Borgatta, E.F. (1964). The structure of personality characteristics. Behavioral Science, 9, 8-17. https://doi.org/10.1002/bs.3830090103

Chomsky, N. (2000). New Horizons in the Study of Language and Mind. Cambridge: Cambridge University Press.

Grof, S. (2000). Psychology of the Future. New York: State University of New York Pressm. Habermas, T., \& de Silveira, C. (2008). The development of global coherence in life narratives across adolescence: Temporal, causal, and thematic aspects. Developmental Psychology, 44, 707-721. https://doi.org/10.1037/00121649.44.3.707

Haken, G. (1995). Erfolgsgeheimnisse der Natur: Synergetik, die Lehre vom Zusammenwirke. Reinbek bei Hamburg: Rowohlt.

Hall, C. (1970). Lindsey G. Theories of Personality. New York: John Wiley and Sons.

Hammack, P.L. (2008). Narrative and the cultural psychology of identity. Personality and Social Psychology Review, 12, 222-247. https://doi. org/10.1177/1088868308316892

Harley, T. (2009). Talking the talk: Language, psychology and science. Hove: Psychology Press. https://doi.org/10.4324/9780203853030

Kelly, G.A. (1955). The Psychology of Personal Constructs (Vols. 1-2). New York: Norton.

Kettell, R.B. (1943). The description of personality: Basic traits resolved intoclusters. Journal of Abnormal and Social Psychology, 38, 476-506. https://doi.org/10.1037/h0054116

Maslow, A.H. (1991). Critique of self-actualization theory. The Journal of Humanistic Education and Development, 29 (3), 103-108. https://doi. org/10.1002/j.21644683.1991.tb00010.x

McCrae, R.R., Costa, P.Jr., Martin, T.A., Oryol, V.E., Rukavishnikov A.A., ... Urbánek, T. (2004). Consensual validation of personality traits across cultures. Journal of Research in Personality, 38, 179-201. https://doi.org/10.1016/S00926566(03)00056-4

McKinley, J.C, \& Hathaway, S.R. (1944). A multiphasic personality schedule (Minnesota): V. Hysteria, Hypomania, and Psychopathic Deviate. Journal of Applied Psychology, 28, 153-174. https://doi.org/10.1037/h0059245

McLean, K., Pasupathi, M., \& Pals, J. (2007). Selves creating stories creating selves: a process model of self-development. Personality and Social Psychology Review, 11 (3), 262-278. https://doi.org/10.1177/1088868307301034 
Menn, L. (2016). Psycholinguistics: Introduction and Applications ( $2_{\text {nd }}$ ed.). San Diego: Plural Publishing, Inc.

Osgood, Ch. (1956). Method and Theory in Experimental Psychology. Oxford.

Schwartz, S.H., Cieciuch, J., Vecchione, M., Davidov, E., Fischer, R., Beierlein, C., ... Dirilen-Gumus, O. (2012). Refining the theory of basic individual values. Journal of Personality and Social Psychology, 103, 663-688. https://doi.org/10.1037/ a0029393

Steinberg, D.D., \& Sciarini, N.V. (2013). An Introduction to Psycholinguistics (2nd ed.). Routledge. London.

Titchener, E.B. (1901-1906). Experimental Psychology: A Manuel of laboratory Practice. New-York, London: Macmillan and Co.

\section{References}

Ananev, B.G. (1968). Chelovek kak predmet poznaniya [Human as a Subject of Knowledge]. Leningrad: LGU [in Russian].

Anohin, P.K. (1975). Ocherki po fiziologii funkcionalnyh system [Essays on the physiology of functional systems]. Akademiya medicinskih nauk SSSR. Moscow: Medicina [in Russian].

Artemeva, E.Yu. (1999). Osnovy psihologii sub'ektivnoj semantiki [Fundamentals of the Psychology of Subjective Semantics]. Moscow: Nauka; Smysl [in Russian].

Bogdanov, V.A. (1987). Sistemologicheskoe modelirovanie lichnosti $v$ socialnoj psihologii [Systemological Modeling of Personality in Social Psychology]. Leningrad: Izd-vo LGU [in Russian].

Brushlinskij, A.V. (2002). Psihologiya sub'ekta: individa i gruppy [Psychology of the subject: the individual and the group]. Psihologicheskij zhurnal - Psychology Journal, 23 (1), 72-80 [in Russian].

Vundt, V. (2002). Vvedenie v psihologiyu [Introduction to Psychology]. St. Petersburg: Piter [in Russian].

Gamezo, M.V., \& Domashenko, I.A. (Eds.). (2004). Atlas po psihologii [Atlas of Psychology]. Moscow: Pedagogicheskoe obshchestvo Rossii [in Russian].

Dyakov, S.I. (2014). Model semanticheskogo analiza i ocenki sub'ektnosti lichnosti [Model of semantic analysis and assessment of personality subjectivity]. Psihologicheskaya diagnostika - Psychological Diagnosis, 1, 36-56 [in Russian].

Dyakov, S.I. (2015). Subektnost pedagoga. Semanticheskie modeli i tekhnologiya issledovaniya [Subjectivity of the Teacher. Semantic Models and Research Technology] (2nd ed.). Moscow: FLINTA: Nauka [in Russian].

Dyakov, S.I. (2016a). Mekhanizm «sdviga motiva na cel»v semanticheskoj sisteme psihicheskoj samoorganizacii sub'ekta [The Mechanism of «Motive-to-Target Shift» in the Semantic System of the Subject's Mental Self-Organization]. Teoreticheskaya i eksperimentalnaya psihologiya - Theoretical and Experimental Psychology, 9 (4), 87-100 [in Russian].

Dyakov, S.I. (2016b). Semantika samoorganizacii cheloveka kak sub'ekta zhizni. Osnovy psihologii sub'ekta [Semantics of Human Self-Organization as a Subject of Life. Basics of the Psychology of the Subject]. St. Peterburg: Prospekt Nauki [in Russian].

Dyakov, S.I. (2017). Psihosemanticheskij podhod $\mathrm{v}$ metodologii issledovaniya samoorganizacii cheloveka kak sub'ekta zhizni [Psychosemantic Approach to the 
Methodology of the Study of Human Self-Organization as A Subject of Life].

Mir psihologii - World of Psychology, 4, 148-157 [in Russian].

Dyakov, S.I. (2018). Psihicheskaya samoorganizaciya cheloveka kak sub'ekta zhizni. Semanticheskij princip [Mental Self-Organization of a Person as a Subject of Life. Semantic Principle]. Izvestiya Irkutskogo gosudarstvennogo universiteta. Seriya Psihologiya - News of Irkutsk State University. Psychology Series, 23, 15-27 [in Russian].

Zajceva, Yu.E. (2016). Ya-narrativ kak instrument konstruirovaniya identichnosti: ekzistencialno-narrativnyj podhod [I-narrative as a Tool for Constructing Identity: An Existential-Narrative Approach]. Vestnik SPbGU - Bulletin of St. Petersburg State University, 16 (1), 118-136 [in Russian].

Karvasarskij, B.D. (2002). Psihoterapiya [Psychotherapy] (2nd ed.). St. Peterburg: Piter [in Russian].

Levin, K. (2001). Dinamicheskaya psihologiya [Dynamic Psychology]. (Transl. E. Patyaeva \& D. Leontev). Moscow: Smysl [in Russian].

Leontev, D.A. (2003). Psihologiya smysla: priroda, stroenie i dinamika smyslovoj realnosti [Psychology of meaning: Nature, Structure and Dynamics of Semantic Reality]. Moscow: Smysl [in Russian].

Lefevr, V. (1991). Formula cheloveka: Kontury fundamentalnoj psihologii [Human Formula: The Contours of Fundamental Psychology]. Moscow: Progress [in Russian].

Lomov, B.F. (1984). Metodologicheskie $i$ teoreticheskie problemy psihologii [Methodological and Theoretical Problems of Psychology]. Moscow: Nauka [in Russian].

Lomov, B.F. (1996). Sistemnost v psihologii [Consistency in Psychology]. Moscow: Izd-vo «Institut prakticheskoj psihologii», Voronezh: NPO «MODEK» [in Russian].

Menegeti, A. (2015). Vvedenie v ontopsihologiyu [Introduction to Ontopsychology]. Moscow: Izdatelstvo: BF «Ontopsihologiya» [in Russian].

Merlin, V.S. (2005). Psihologiya individualnosti: Izbrannye psihologicheskie Trudy [Psychology of personality: Selected Psychological Works]. In E.A. Klimov (Ed.). Moscow: Izdatelstvo Moskovskogo psihologo-socialnogo instituta [in Russian].

Meshcheryakov, B.G., \& Zinchenko, V.P. (Eds.). (2003). Bolshoj psihologicheskij slovar [Great Psychological Dictionary]. Moscow: Izdatelstvo: Prajm-Evroznak [in Russian].

Mej, R. (1997). Lyubov i volya [Love and Will]. Moscow: Refl-buk; Kyiv: Vakler [in Russian].

Nikandrov, V.V. (2003). Metod modelirovaniya v psihologii [Modeling Method in Psychology]. St. Peterburg: Rech [in Russian].

Petrenko, V. (2005). Osnovy psihosemantiki [The Basics of Psychosemantics]. St. Petersburg: Piter [in Russian].

Prigozhin, I., \& Stengers, I. (1986). Poryadok iz haosa: Novyj dialog cheloveka $s$ prirodoj [Order out of Chaos: A New Dialogue Between Human and Nature]. (Trans. from English). In V.I. Arshinov, Ju.L. Klimontovich \& Ju.V. Sachkov (Eds.). Moscow: Progress [in Russian].

Sartr, Zh. (2000). Bytie i nichto. Opyt fenomenologicheskoj ontologii [Being and nothing. The Experience of Phenomenological Ontology]. Moscow: Respublika [in Russian]. 
Sergienko, E.A. (2013). Problema sootnosheniya ponyatij sub'ekta i lichnosti [The problem of the relationship between the concepts of subject and personality]. Psihologicheskij zhurnal - Psychology Journal, 34 (2), 5-16 [in Russian].

Serkin, V.P. (2017). Psihosemantika [Psychosemantics]. Moscow: Yurajt [in Russian].

Fransella, F., \& Bannister, D. (1987). Novyj metod issledovaniya lichnosti [A new method of researching personality]. Moscow: Progress [in Russian].

Fromm, E. (2006). Begstvo ot svobody. Chelovek dlya sebya [Escape from freedom. Human for Himself]. Moscow: ACT [in Russian].

Chepeleva, N., \& Rudnickaya, S. (2019). Dyskursyvni Tekhnolohii Osobystosti Shcho Samoproektuietsia [Discursive technologies of Self-Developing Personality]. Psiholingvistika - Psycholinguistics, 25 (1), 363-383. https://doi. org/10.31470/2309-1797-2019-25-1-363-383 [in Ukrainian].

Shvarc, S.H. (2008). Kulturnye cennostnye orientacii: priroda i sledstviya nacionalnyh razlichij [Cultural value orientations: Nature and consequences of national differences]. Psihologiya - Psychology, 2, 36-67 [in Russian].

Aizenk, H.J. (1997). Personality and experimental psychology: The unification of psychology and the possibility of a paradigm. Journal of Personality and Social Psychology, 73, 1224-1237. https://doi.org/10.1037/0022-3514.73.6.1224

Allport, G.W., \& Odbert, H.S. (1936). Trait-names: A psycho-lexical study. Psychological Monographs, 47, (No. 211). https://doi.org/10.1037/h0093360

Almagor, M., Tellegen, A., \& Waller, N. (1995). The Big Seven Model: A cross-cultural replication and further exploration of the basic dimensions of natural language of trait descriptions. Journal of Personality and Social Psychology, 69, 300-307. https://doi.org/10.1037/0022-3514.69.2.300

Ashton, M., Kibeom, L., Perugini, M., Szarota, P., de Vries, R.E., ... de Raad, B. (2004). A Six-Factor Structure of Personality-Descriptive Adjectives: Solutions From Psycholexical Studies in Seven Languages. Journal of Personality and Social Psychology, 86 (2), 356-366. https://doi.org/10.1037/0022-3514.86.2.356

Borgatta, E.F. (1964). The structure of personality characteristics. Behavioral Science, 9, 8-17. https://doi.org/10.1002/bs.3830090103

Chomsky, N. (2000). New Horizons in the Study of Language and Mind. Cambridge:Cambridge University Press.

Grof, S. (2000). Psychology of the future. New York: State University of New York Pressm. Habermas, T., \& de Silveira, C. (2008). The development of global coherence in life narratives across adolescence: Temporal, causal, and thematic aspects. Developmental Psychology, 44, 707-721. https://doi.org/10.1037/00121649.44.3.707

Haken, G. (1995). Erfolgsgeheimnisse der Natur: Synergetik, die Lehre vom Zusammenwirke. Reinbek bei Hamburg: Rowohlt.

Hall, C. (1970). Lindsey G. Theories of Personality. New York: John Wiley and Sons.

Hammack, P.L. (2008). Narrative and the cultural psychology of identity. Personality and Social Psychology Review, 12, 222-247. https://doi. org/10.1177/1088868308316892

Harley, T. (2009). Talking the talk: Language, psychology and science. Hove: Psychology Press. https://doi.org/10.4324/9780203853030

Kelly, G.A. (1955). The psychology of personal constructs (Vols. 1-2). New York: Norton.

Kettell, R.B. (1943). The description of personality: Basic traits resolved intoclusters. Journal of Abnormal and Social Psychology, 38, 476-506. https://doi.org/10.1037/h0054116 
Maslow, A.H. (1991). Critique of self-actualization theory. The Journal of Humanistic Education and Development, 29 (3), 103-108. https://doi. org/10.1002/j.21644683.1991.tb00010.x

McCrae, R.R., Costa, P.Jr., Martin, T.A., Oryol, V.E., Rukavishnikov A.A., ... Urbánek, T. (2004). Consensual validation of personality traits across cultures. Journal of Research in Personality, 38, 179-201. https://doi.org/10.1016/S00926566(03)00056-4

McKinley, J.C, \& Hathaway, S.R. (1944). A multiphasic personality schedule (Minnesota): V. Hysteria, Hypomania, and Psychopathic Deviate. Journal of Applied Psychology, 28, 153-174. https://doi.org/10.1037/h0059245

McLean, K., Pasupathi, M., \& Pals, J. (2007). Selves creating stories creating selves: a process model of self-development. Personality and social psychology review, 11 (3), 262-278. https://doi.org/10.1177/1088868307301034

Menn, L. (2016). Psycholinguistics: Introduction and Applications (2nd ed.). San Diego: Plural Publishing, Inc.

Osgood, Ch. (1956). Method and Theory in Experimental Psychology. Oxford.

Schwartz, S.H., Cieciuch, J., Vecchione, M., Davidov, E., Fischer, R., Beierlein, C., ... Dirilen-Gumus, O. (2012). Refining the theory of basic individual values. Journal of Personality and Social Psychology, 103, 663-688. https://doi.org/10.1037/ a0029393

Steinberg, D.D., \& Sciarini, N.V. (2013). An Introduction to Psycholinguistics (2nd ed.). Routledge. London.

Titchener, E.B. (1901-1906). Experimental Psychology: A Manuel of laboratory Practice. New-York, London: Macmillan and Co.

\section{ПРИЛОЖЕНИЯ}

\section{Приложение А}

Протокол экспертной оценки структурной модели семантического анализа и оценки субъектности личности

Анализ конструктов качеств личности по критериям социально-ролевой идентификации (по результатам модифицированной методики репертуарных решеток Дж. Келли)

Эксперт

(указать код имени или ФИО; профессия (специальность), учен. степень, звание)

\section{ИНСТРУКЦИЯ}

Вам надлежит дать свою оценку представленной психологической модели семантических конструктов субъектности личности (Табл. А. 2, на последней стр.).

Понятие «семантический конструкт» означает полярные качества, по которым можно охарактеризовать человека, например: «активность пассивность». Выполните следующие задания.

1. Отметьте ниже в графе 4 (Табл. А. 1 представляет собой уже конечный материал полученный на основе структуры конструктов в предыдущем исследовании) соответствует ли конкретный конструкт качеств данной шкале структуры личности, например, конструкт № 1 шкалы 1.1 «Волевые функции»: «независимость - конформность или подчиненность». Сделайте пометку в 
графе 4: поставьте птичку, если считаете, что соответствует, или поставьте крестик, если не соответствует. Если нет, тогда к какой другой шкале относится данный конструкт? Запишите это тоже в графе 4, например - 3.1.

2. Добавьте еще, по Вашему усмотрению, подходящие семантические конструкты в нижних строках каждой шкалы или на последней странице бланка.

3. Отметьте перед графой 1 (птичкой) имеет ли данный конструкт качеств личности характер субъектности.

Понятия «субъект», «субъектность» поведения, деятельности личности использованы в значении - сознательная самодетерминированная активность человека, его способность самостоятельно делать выбор и принимать решение, реализовывать свои намерения. Если инструкция понятна, приступайте к работе.

Примечание. Полное содержание конструктов и структура распределения к табл. А. 1, представлены в наших публикациях (Дьяков, 2015, 2016).

Возможно, Вы хотите предложить добавить еще некоторые шкалы или внести изменения в данную структурную модель семантического анализа субъектности личности.

Таблица А. 1. Шкалы полярных качеств (черт, свойств) личности

\begin{tabular}{|c|c|c|c|}
\hline № & Качества идентичности & Противоположные качества & - \\
\hline 1 & 2 & 3 & 4 \\
\hline \multicolumn{4}{|c|}{ І. Индивидуально психологическая сфера (ИПС) } \\
\hline \multicolumn{4}{|c|}{ 1. Функциональный уровень } \\
\hline \multicolumn{4}{|c|}{ Базовые процессуальные психологические качества личности } \\
\hline \multicolumn{4}{|c|}{ 1.1. Волевые функции } \\
\hline $1^{*}$ & Независимость & Конформность, подчиненность & \\
\hline $2 *$ & Смелость & Трусость, робость & \\
\hline $3^{*}$ & Сила воли, стойкость, твердость & Слабость воли & \\
\hline $4 *$ & Активность & Пассивность & \\
\hline $5^{*}$ & Собранность, организованность & Несобранность & \\
\hline $6^{*}$ & Решительность & Нерешительность & \\
\hline $7 *$ & Настойчивость в достижении цели & «Плывут по течению» & \\
\hline $8^{*}$ & Рискованность & Осторожность, нерешительность & \\
\hline \multicolumn{4}{|c|}{ 1.2. Эмоциональные функции } \\
\hline \multirow[t]{2}{*}{1} & Эмоциональность & Неэмоциональность, холодность чувств & \\
\hline & 2 Спокойствие, уравновешег & $\begin{array}{r}\text { тьВспыльчивость, беспокойность, } \\
\text { нервность, неуравновешенность }\end{array}$ & \\
\hline 3 & Веселость, радостность & Невеселые, хмурые & \\
\hline 4 & Стыдливость & Раскованность & \\
\hline 5 & Азартные & Неазартные & \\
\hline \multicolumn{4}{|c|}{ 1.3. Интеллектуальные функции } \\
\hline $1 *$ & Рассудительность & Безрассудство & \\
\hline 2 & Компетентность & Некомпетентность & \\
\hline
\end{tabular}




\begin{tabular}{lll}
\hline 3 & Умные, имеют острый ум & Дураки, тупые \\
4 & Грамотность & Безграмотность \\
5 & Начитанность & Мало читают \\
6 & Образованность & Необразованность \\
7 & Интеллектуальность, & Посредственность \\
& информированность, эрудированность & низкий интеллект \\
8 & Развитая интуиция & Неразвитая интуиция \\
9 & Мудрость & Формальная логика
\end{tabular}

2. Стойкие осознанные отношения (высшие чувства-убеждения-мотивы) Индивидуально психологическая сфера (ИПС). Направленность личности Мотивационный уровень

\section{1. Моральные чувства -мотивы (добро)}

1* Верность, надежность, преданность, хороший друг

2* Старательность

$3^{*}$ Порядочность

4 Сопереживание, сочувствие

$5^{*}$ Категоричность

6* Трудолюбие

7 * Обязательность, ответственность, серьезность, трезвость, осторожность, осмотрительность

8* Чуткость, милосердие, сердечность, безотказность, взаимопомощь, дружелюбие, доброжелательность, приветливость, человечность, гуманность, доброта, добродушие, доброжелательность

9* Эгоизм, себялюбие, эгоцентризм

10 Корыстность

11 Жадность, скаредность, бережливость

12 Справедливость, честность

13 Воспитанность

14* Заботливость

15* Строгость, требовательность

16* Самоуверенность, уверенность в себе

17 Откровенность, открытость, правдивость

18* Тщеславие, важничанье, высокомерие, нетерпимость

19 Нежность, мягкость

20 Зависть

21 Злопамятность

22* Упрямство, неуступчивость
Предательство, ненадежность, легкомысленность, склонность к измене

Безразличие в работе

Подлость

Холодность к людям

Лояльность

Лень

Беззаботность, послушность,

небрежность, легкомысленность, неосмотрительность

Безразличие, нечувствительность, бессердечие, черствость, недружелюбность, неприветливость, негуманность, злобность, недоброжелательность

Альтруистичность, самоотверженность Бескорыстность

Щедрость, транжира

Нечестность

Невоспитанность

Безразличие

Мягкость, лояльность

Неуверенность

Лицемерие, хитрость, ханжество

Простота, терпимость к другим, толерантность

Грубость, агрессивность

Сорадость

Умение прощать

Покладистость, неприхотливость 
23* Скромность, сдержанность

24* Аккуратность

25 Компромиссность

26 Культурные, воспитанные

27 * Беспокойство, серьезное отношение к здоровью, здоровый образ жизни

28 Внимательность к людям

29 Понимание, уважение к людям
Нескромность, вредность, нахальность

Неряшливость

Бескомпромиссность

Некультурность

Разгульность, беззаботное отношение

к здоровью

Внимательность к людям

Неуважение к людям

\section{2. Эстетичные чувства- мотивы (красота)}

1 Духовность, духовная близость

2* Стремление быть красивым, желание нравиться

4 Любвеобильные, сексуальные

5 Красота, нравятся, приятные, симпатия, обворожительность

6 Любовь к прекрасному

7 Хороший вкус

9 Являются положительным. идеалом
Приземленность, духовно чужие

Отсутствует желание нравиться

Безразличные, незаинтересованные сексуально, пуритане

Некрасивые, неприятие, антипатия

Отсутствие чувства прекрасного

Не имеют вкуса

являются антиподом

\section{3. Интеллектуальные чувства - мотивы (истина)}

1 Общность интересов

2* Отношение к учебе позитивное, жажда, стремление к знанию

3* Интеллектуально развиваются

4* Любознательность, познавательная активность, интересуются новым

5* Рассудительность, реализм, рационализм, практичность, прагматизм

6 Чувство юмора, любят шутить

7 Стремление к лучшей жизни

8* Спонтанность, импровизация, экспромт

$9 *$ Генератор идей
Расхождение интересов

Негативное отношение к учебе, легкомысленность

Отсутствие склонности к познанию

Нет заинтересованности, не

интересуются ни чем

Непрактичность, идеализм,

романтики, фантазеры

Отсутствие чувства юмора

Безразличие к новому

Интеллектуальный консерватизм

Безыдейный, интеллектуально

пассивный

\section{3. Смысложизненный уровень}

\section{Интегральные ценности-мотивы}

\section{1. Терминальные ценности-мотивы}
1* Счастливые
Несчастливые
Любимые, нравятся, хорошие
Нелюбимые, нехорошие
2 Духовные ценности
Материальные ценности

\section{2. Инструментальные ценности-мотивы}

$1 *$ Жизнерадостность, оптимизм,

Пессимизм, апатия энтузиазм

1 * Самопожертвование

Эгоизм, ради удовольствия 
ІІ. Индивидуально-действенная сфера (ИДС)

4. Характеристика поведения и деятельности (манера, стиль). Характер и способности

\section{1. Проявления поведения}

1 Скорые, подвижные

2 Странные

3 Терпеливые, усидчивые

4* Сила характера

5 Раскованные
Медлительные

Нормальные

Нетерпеливые, беспокойные

Слабохарактерные

Скованные

\section{2. Привычки, склонности}

1 Курят

2 Имеют полезные привычки

3 Домоседы

4 Любят выпить
Не курят

Имеют плохие привычки

Любят путешествовать

Непьющие

\section{3. Профессиональные склонности}

1 Любовь к своему делу

Безразличие к работе

2 Любовь к людям природе искусству, спорту

Безразличие

\section{4. Профессионально-деловые способности ${ }^{* * * *}$}

1* Профессионализм, знает свое дело, Дилетантство, неспециалист специалист, мастер

2* Авторитетный, уважаемый

3* Хозяйственный

4* Лидер, организатор

5* Умение добиваться цели

6* Самоорганизованность

7* Целенаправленность

8* Умение учить других

9* Яркая личность, неординарная

$10 *$ Пунктуальность, не любит пустые разговоры

11* Работоспособные, деловые

12* Умеют зарабатывать деньги
Неавторитетный, неуважаемый

Бесхозяйственный

Не способный организовать, склонный подчиняться

Неумения добиваться цели

Неорганизованность

Разболтанность

Неумение учить

«Серая», невзрачная

Тратят время зря

Неделовые, апатичные, несобранные

Не способные зарабатывать деньги

\section{5. Способности творческие}

$1 *$ Предприимчивость, инициативность

$2 * \quad$ Гибкость поведения

3* Стремление овладеть профессией

4* Умение вызывать интерес, привлечь внимание

5* Артистическая

6* Оригинальные

7* Саморазвитие, усовершенствование способностей, знаний

$8^{*}$ Умеет интересно проводить время
Безынициативность

Консервативность

Надеются на помощь

Неумение заинтересовать

Безманерность

Формальные, консервативные

Отсутствие стремления развиваться

Не умеет проводить время 


\section{6. Коммуникативные особенности}

1 Приятные в общении, интересные, легко с ними общаться

2 Умение общаться, общительность, коммуникабельность

3 Взаимопонимание в общении, дружелюбие, много друзей

4 Умение строить разговор, говорливость, хороший собеседник

5 Располагает к себе

6 Умение дать совет, подбодрить
Неприятные, нудные

Неумение общаться, замкнутые, отгороженные, некоммуникабельные Конфликтность, скандальность

Неумение строить разговор, несговорчивость, плохой собеседник, молчаливость

Трудно открыться

Неспособность помочь

Таблица А. 2. Структурная модель семантического анализа и оценки субъектности личности

\section{Сферы анализа и оценки}

\section{І. Индивидуально-психологическая сфера (ИПС)}

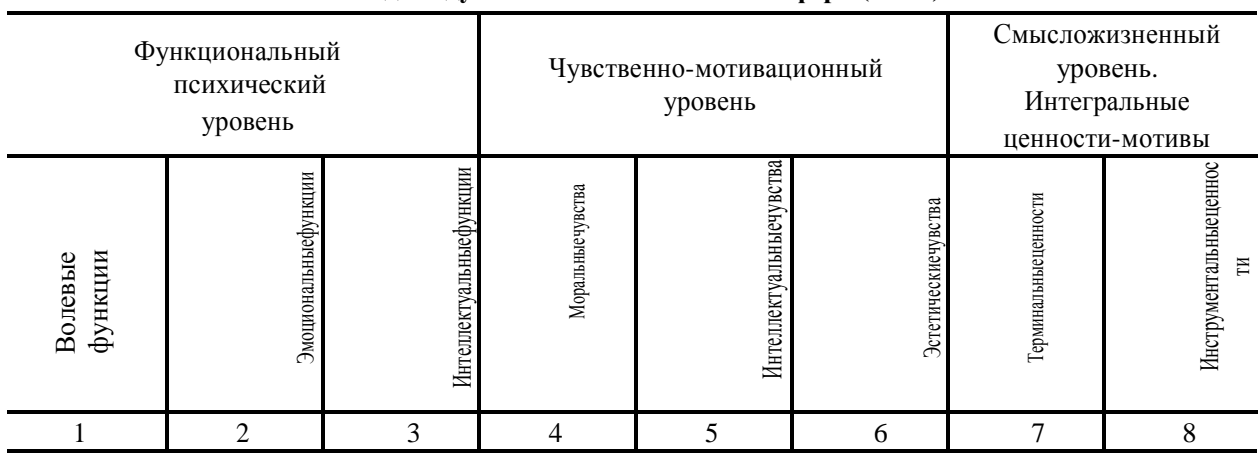

II. Индивидуально-действенная сфера (ИДС)

Характеристика поведения и деятельности (манера, стиль).

Характер и способности

\begin{tabular}{|c|c|c|c|c|c|}
\hline \multirow{2}{*}{ 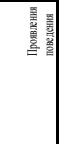 } & \multirow{2}{*}{\begin{tabular}{r|} 
产 \\
总 \\
产
\end{tabular}} & \multicolumn{4}{|c|}{ Способности и склонности } \\
\hline & & $\begin{array}{c}\text { Профессиональные } \\
\text { качества, склонности }\end{array}$ & $\begin{array}{c}\text { Профессионально- } \\
\text { деловые способности }\end{array}$ & $\begin{array}{l}\text { Творческие } \\
\text { способности }\end{array}$ & $\begin{array}{r}\text { Коммуникатив- } \\
\text { ные качества }\end{array}$ \\
\hline 9 & 10 & 11 & 12 & 13 & 14 \\
\hline
\end{tabular}

III. Внешне-адаптивная сфера (ВАС)

Восприятие себя, понимание своего положения

в условиях внешней среды

\begin{tabular}{|c|c|c|c|c|c|}
\hline $\begin{array}{c}\text { Внешний } \\
\text { вид } \\
\end{array}$ & $\begin{array}{c}\text { Физические } \\
\text { качества }\end{array}$ & $\begin{array}{l}\text { Ролевые } \\
\text { позиции } \\
\end{array}$ & $\begin{array}{c}\text { Возрастные } \\
\text { данные }\end{array}$ & $\begin{array}{c}\text { Социальное } \\
\text { положение } \\
\end{array}$ & $\begin{array}{c}\text { Внешние } \\
\text { обстоятельства }\end{array}$ \\
\hline 15 & 16 & 17 & 18 & 19 & 20 \\
\hline \multicolumn{6}{|c|}{ IV. Субъектная сфера (CC) } \\
\hline \multicolumn{6}{|c|}{ Факторы самостоятельной активности } \\
\hline \multicolumn{2}{|c|}{ Общая субъектность } & \multicolumn{2}{|c|}{ Интросубъектный уровень } & \multicolumn{2}{|c|}{ Экстрасубъектный уровень } \\
\hline \multicolumn{2}{|r|}{21} & \multicolumn{2}{|r|}{22} & \multicolumn{2}{|r|}{23} \\
\hline
\end{tabular}




\section{АННОТАЦИЯ}

Цель. На основе психолингвистического подхода, широко представленного в мировой персонологии и психосемантике, раскрывающих субъективные описательные характеристики личности, сделана попытка построения модели и методики диагностики психической самоорганизации личности (ПСО). Методы и методики. В ракурсе субъектной парадигмы и методологии системносинергетического подхода представлен психолингвистический метод теоретического структурирования и систематизации научно-теоретических данных (психолингвистических, психологических и философских) в построении категориально-концептуальной модели субъектности в ПСО. На основе метода категориально-концептуального моделирования, разработана модель и методика семантического анализа и оценки субъектной самоорганизации личности на основе индивидуальных особенностей опыта социально-ролевой идентификации, отражающих характеристики чувств и конструкты понимания, детерминирующих сознательную волю субъекта.

Результаты. Выделены психолингвистические шкалы семантических конструктов психического (функцианальные и мотивационные) и деятельностного (профессионально-деловые и творческие) уровней субъектности. Эмпирический материал отражает верификацию семантической модели и методики. Методом сбора эмпирических данных послужили модифицированные репертуарные решетки Дж. Келли и экспертная оценка в семантическом анализе и классификации конструктов. Массив полученных конструктов (N=2000) отражает известные категориальноконцептуальные аспекты психических явлений (процессов - состояний свойств) и внешних средовых и социокультурных характеристик, раскрывая, таким образом, социально-психологические стороны социально-ролевой идентификации личности, что позволяет производить анализ и оценку субъектности.

Выводы. Представленные семантические шкалы качеств и свойств личности (факторы социально-психологической идентификации) раскрывают системную взаимосвязь и уровневую структуру ПСО, а также позволяют сделать оценку субъектности.

Ключевые слова: категориально-концептуальное моделирование, психическая самоорганизация, системно-синергетический подход, субъект, субъектность личности, социально-ролевая идентификация.

\section{Дьяков Сергій. Семантична репрезентація соціально-рольової ідентифікації в} суб'єктній самоорганізації особистості

\section{АНОТАЦІЯ}

Мета. На основі психолінгвістичного підходу, широко представленого в світовій персонології i психосемантиці, які розкривають суб'єктивні описові характеристики особистості, зроблена спроба побудови моделі та методики діагностування психічної самоорганізації особистості (ПСО). 
Методи і методики. У ракурсі суб'єктної парадигми і методології системносинергетичного підходу представлений психолінгвістичний метод теоретичного структурування й систематизації науково-теоретичних даних (психолінгвістичних, психологічних і фрілософських) у побудові категоріальноконцептуальної моделі суб'єктності в ПСО. На основі методу категоріальноконцептуального моделювання розроблена модель і методика семантичного аналізу та оцінки суб'єктної самоорганізації особистості на основі індивідуальних особливостей досвіду сочіально-рольової ідентифікації, що відображають характеристики почуттів і конструкти розуміння, що детермінують свідому волю суб'єкта.

Результати. Виділено психолінгвістичні шкали семантичних конструктів психічного (функціональні й мотиваційні) і діяльнісного (професійно-ділові та творчі) рівнів суб'єктності. Емпіричний матеріал відображає верифікацію семантичної моделі й методики. Методом збору емпіричних даних слугували модифіковані репертуарні решітки Дж. Келлі та експертна оцінка в семантичному аналізі та класифікації конструктів. Масив отриманих конструктів ( $N=2000)$ відображає відомі категоріально-концептуальні аспекти психічних явищ (прочесів - станів - властивостей) і зовнішніх середовищних та соціокультурних характеристик, розкриваючи таким чином сочіальнопсихологічні сторони соціально-рольової ідентифрікації особистості, що дозволяє проводити аналіз і оцінку суб'єктності.

Висновки. Представлені семантичні шкали якостей і властивостей особистості (фактори сочіально-психологічної ідентифікації) розкривають системну взаємозв'язок і рівневу структуру ПСО, а також дозволяють зробити оцінку суб'єктності.

Ключові слова: категоріально-концептуальне моделювання, психічна самоорганізація, системно-синергетичний підхід, суб'єкт, суб'єктність особистості, соціально-рольова ідентифрікація. 